\title{
Türkiye’de Mali Demokrasi: 2010-2019 Dönemi İçin Bir İnceleme
}

\author{
Ahmet ULUSOY*, Mehmet ELA**
}

ÖZ

Zorunlu kamu harcamalarını karşıladıktan sonra geriye kalan vergi gelirlerinin toplam vergi gelirlerine yüzdesini ölçen mali demokrasi indeksi, zorunlu harcamalar karşısında bütçe üzerindeki kontrolü, mali alanı ve hareket kabiliyetini yansıtmaktadır. Mali demokrasi indeksindeki artış kamunun mali manevra kabiliyetini arttırırken, konjonktüre göre daha hızlı ayarlama yapabileceğini göstermektedir. Ayrıca, mali demokrasi indeksindeki artış, vatandaşların kamu harcamaları konusunda daha çok söz sahibi ve bütçenin katılığının sınırlı olduğunu vurgulamaktadır. Geçmiş politika yapıcıların mali kararları zamanla vergi gelirlerini ve kamu harcamalarının katılığını etkilemiş ve birtakım harcamalar zorunlu hale gelmiştir. Benzer şekilde Türkiye'de de vergi gelirleri geçmiş dönem politikalarından etkilenirken bazı harcamaların yapılması zorunlu (katı) hale gelmiştir. Zorunlu harcamalardaki artış ise mali alanı daraltmakta ve bütçenin esnekliğini düşürmektedir. Bununla beraber, çalışmanın sonuçlarına göre Türkiye'de mali demokrasi indeksi pozitiftir. Yani, iradi harcamalar (mali alan) son yıllarda artmaktadır.

Anahtar Kelimeler: Mali Demokrasi, Zorunlu Kamu Harcamaları, Bütçe Esnekliği

JEL Sinıflandırması: E02, E60, E64

\section{Fiscal Democracy in Turkey: A Research for 2010-2019 Period}

\begin{abstract}
Fiscal democracy index, which measures the percentage of tax revenues remaining from compulsory public expenditures to total tax revenues, reflects the control over the budget, fiscal space and mobility in the face of mandatory expenditure. While increase in fiscal democracy index increases the public's fiscal maneuverability, it shows that it can make the fiscal adjustment according to conjuncture faster. Past policymakers' fiscal decisions have influenced tax revenues and the rigidity of public spending, and some expenditures have become compulsory. Similarly, in Turkey, while tax revenues are influenced by previous period policies, some expenditures have become compulsory. The increase in mandatory expenditures narrows the fiscal space and reduces the flexibility of the budget. In addition, according to the results of the study, the fiscal democracy index is positive in Turkey. That is, voluntary spending (fiscal space) has been increasing in recent years.
\end{abstract}

Keywords: Fiscal Democracy, Mandatory Public Expenditures, Flexibility of Budget

JEL Classification: E02, E60, E64

Geliş Tarihi / Received: 12.08.2020 Kabul Tarihi / Accepted: 01.12.2020 Doi: 10.17541/optimum. 779719

\footnotetext{
* Prof. Dr., Beykent Üniversitesi, İktisadi ve İdari Bilimler Fakültesi, İktisat Bölümü, ahmetulusoy@ @eykent.edu.tr, ORCID: 0000-0001-8407-2770.

** Dr. Öğr. Üyesi, Osmaniye Korkut Ata Üniversitesi, İktisadi ve İdari Bilimler Fakültesi, Siyaset Bilimi ve Kamu Yönetimi Bölümü, mehmetela@osmaniye.edu.tr, ORCID:0000-0001-7341-6312.
} 


\section{GİRIŞ}

Demokrasi, egemenliğin kaynağını halktan aldığı yönetim biçimini ifade etmektedir. Halkın seçtiği temsilciler yoluyla ülkeyi ilgilendiren sosyal, yönetsel ve benzeri konularla birlikte mali konularda önemli kararlar alınmaktadır. Diğer yandan demokrasinin doğumu da birtakım mali gelişmelerin sonucudur. Bu açıdan geçmişten günümüze demokrasi ve maliye ilişkisi varlığını sürdürmektedir.

Geçmişte kamu harcamaları ve vergi gelirleri konusunda alınan kararlar (politika mirasları) güncel karar vericilerin ve dolayısıyla da halkın, bütçe fonksiyonları üzerinde söz sahipliğinin azalmasını ve olumsuz ekonomik ve mali gelişmelere karşı mali alanın daralmasını ifade etmektedir. Bu anlamda geçmiş politika miraslarının günümüz gelir ve harcama düzeyleri üzerinde birtakım etkileri vardır.

Ülkelerin çoğunda, yeni seçilen hükümetlerin kendi ekonomik politikalarını oluşturma konusunda sınırlı alanları vardır. Çünkü mali kaynaklarla ilgili kararların çoğu, önceden oluşan zorunlu harcama programları sonucunda kullanılmaktadır. Bu sorun, politika mirasının birikimi olarak bilinmektedir. Buna mali demokrasinin kaybı eşlik etmektedir; yani mevcut politikacıların kamu kaynaklarının nasıl kullanılacağını seçme özgürlüğünün azalması söz konusudur. Sonuç olarak, maliye politikası esnekliğini; yani ekonomik döngüyü stabil hale getirme ve mevcut ekonomik sorunları çözme etkinliği kaybetmektedir.

Politika miraslarının "zaman içinde birikebileceği, seçilmiş hükümetlerin ve parlamentoların seçimlerini sınırlayabileceği ve devletlerin ortaya çıkan sosyal sorunlara yanıt verme kapasitesini azaltabileceği” fikri yeni değildir. Miras alınan politika mirası, bireylerin tercihlerinden daha önemli olarak görülen yasalara, düzenlemelere ve bütçelere dayanan kurumsal üstlenimlerle ileriye aktarılmaktadır. Yasa koyucuların bakış açısından, birikmiş politika mirası zorunlu programlar biçiminde devletin gelirleri mevcut kamu ihtiyaçlarını karşılayacak şekilde tahsis etme kapasitesini engellemektedir. Nitekim, 1970'lerden beri, politika miraslarının birikmesi kamu maliyesi literatüründe önemli bir konu haline gelmiştir. Örneğin, komünist ülkelerde komünizm sonrası eski yönetimlerin birçok mali politika mirasları güncel durumda varlığını korumaya devam etmiştir.

Politika mirasının biriktirilmesine ilişkin literatür oldukça zengindir. Rose (1990), yeni seçilen hükümetlerin mirasını, geçmişte selefleri tarafından yapılan birikmiş taahhütler olarak tanımlamaktadır. Bunun nedeni, çoğu kamu harcama programının süresiz olarak devam etmesidir. Pierson (1998), birikmiş politika miraslarının yeni seçilen hükümetlerin mali tercihlerini kısıtladığını ve ortaya çıkan sosyal ve ekonomik sorunlara yanıt verme kabiliyetini sınırladığını iddia etmektedir (Roženský, 2011: 133).

Politik miras sonucu oluşan katı (zorunlu) harcamalar ve vergi harcamalarını ortadan kaldırmak güncel karar vericiler açısından oldukça zordur. Yani, geçmişte oluşan politika mirasları, hemen değiştirilip ortadan kaldırılamamakta ve kamu maliyesinde ciddi problemlere yol açmaktadır. Örneğin, uzun süredir devam eden politik programlarda ve sosyal güvenlik gibi harcamalarda yaşanan otomatik artışlar, birçok demokratik ülkede yüksek kronik bütçe açıklarına yol açmaktadır. Bunun sonucunda kamu borçları artmakta ve hükümetlerin kıt kaynak dağıtımında özgürlüğü kısıtlanmaktadır. Geçmişten kalan programlara yönelik harcamalar ve borç geri ödemeleri toplamı vergi kaynaklarının büyük bir bölümünü emmektedir. Sonuçta mali alan ve hükümetlerin hareket kabiliyeti (mali demokrasi) daralmakta ve demokratik seçim ortadan kalkmaktadır.

Mali demokrasi, genel olarak Steuerle ve Roeper tarafından geliştirilen bir indeksle ölçülmektedir. 'Mali demokrasi indeksi' olarak adlandırılan ölçünün negatif olması, hükümetlerin vergi gelirleri ile harcamalar konusunda seçim şansının olmadığını göstermektedir. 
İndeksin pozitif olması ise katı (zorunlu) kamu harcamaları yapıldıktan sonra geriye yeterince vergi geliri kaldığını ifade etmektedir.

$\mathrm{Bu}$ çalışmada Türkiye için zorunlu harcamalar irdelenmiş ve mali demokrasi indeksi hesaplanmaya çalışılmıştır. Giriş bölümünün ardından mali demokrasi kavramı ve indeksi açıklanmış, sonrasında zorunlu (katı) kamu harcamaları kavramı irdelenmiştir. 4 nolu başlık altında Türkiye'de zorunlu harcama kalemleri belirlenmiş ve bu kalemlerdeki gelişmeler kısaca irdelenmiştir. Sonrasında Türkiye için mali demokrasi indeksi hesaplanmıştır. 6 nolu başlıkta Türkiye için hesaplanan mali demokrasi indeksi diğer ülkelerle karşılaştırılmış ve ardından sonuca gidilmiştir.

\section{MALİ DEMOKRASİ KAVRAMI VE İNDEKSİ}

Mali demokrasi, güncel seçmenlerin kamu harcamaları ve gelirleri üzerinde ne ölçüde söz sahibi olduğunu, olumsuz ekonomik ve mali koşullar karşısında ne derecede mali alana ve mali açından hareket kabiliyetine sahip olunduğunu ölçmek adına ortaya atılmış bir kavramdır. Mali demokrasi, kamu harcama ve gelirleri yani bütçe üzerinde bugünkü kuşağın daha çok oy hakkı olmasını gerektirmektedir. Geçmiş yasama organlarının uyguladığı harcama ve gelir programlarının güncel dönemde hala uygulamada olması, zorunlu kamu harcamalarını arttırmakta, bu ise hükümetlerin mali alanını kısıtlamakta ve ekonomik şoklara karşı bütçe esnekliğini azaltmaktadır (Streeck ve Mertens, 2013: 32).

Steuerle'ye göre, demokraside mali konular ve özelde ise bütçe üzerinde eşit oy hakkının olması gerekmektedir. Ancak, oylama, sadece oyların politika koşullarında bir fark yaratabileceği ölçüde demokratiktir. Eğer oylanan konuda bir alternatif yoksa oylama da gereksizdir. Mali demokrasinin gereğine işaret eden Steuerle, mali demokrasiyi direkt olarak tanımlamak yerine Roeper'le birlikte geliştirdikleri mali demokrasi indeksi ile açıklamaya çalışmıştır. Buna göre mali demokrasi zorunlu harcamalar (borç servisi dahil) çıkarıldıktan sonra elde ne kadar kamu geliri kaldığı ile ilgilidir (Steuerle, 2016, 2014). Sawhill ve Anrig (2010)'a göre mali demokrasi, bütçenin otomatik pilota bağlanmasıdır. OECD (2013: 14)'e göre ise mali demokrasi, gelecekteki kaynaklar üzerinde geçmiş kararların etkisi olmaksızın maliye politikası konusunda karar verebilme yeteneğini göstermektedir.

Steuerle-Roeper mali demokrasi indeksi, mevcut gelirlerin ne kadarının yasama organ tarafindan oy kullanma gerektirmeyen programlara veya teknik açıdan zorunlu harcama programlarına ayrıldığını ölçmektedir (Steuerle, 2016). Mali demokrasi endeksi, dünün yasa koyucularının yarının bütçe tahsisatlarını ne ölçüde dikte ettiklerinin (etkilediklerinin) bir ölçüsü olarak düşünülebilmektedir. İndeks, kamu harcamalarının farklı sektörler ve politikalar arasında yeniden tahsisinde meclislerin kamu önceliklerini yansıtması için elde edebildikleri karar alanını ölçmektedir (Abdellatif vd., 2019:53).

Mali demokrasi indeksi için öncelikle zorunlu kamu harcamaları (ki ülkelere göre farklılaşmaktadır) ve borç faiz servisi hesaplanmaktadır. Zorunlu harcamalar ve borç faizleri, toplam kamu gelirlerinden çıkartılarak ihtiyari kamu harcamaları için bütçede kalan kamu gelirleri elde edilmektedir. Elde edilen kamu gelirinin toplam kamu gelirlerine oranı ise mali demokrasi indeksini oluşturmaktadır.

Mali demokrasi endeksi aşağıdaki gibi formüle edilebilmektedir.

$$
I_{M D}=\left(1-\frac{Z H}{\sum G}\right) \cdot 100
$$

Formülde, MD: Mali demokrasi indeksini; ZH: Zorunlu harcamaları ve G: Kamu gelirlerini ifade etmektedir. 
Borçların ve zorunlu harcamaların olmaması durumunda indeks 100 değerini almaktadır. Diğer yandan harcamaların tamamı faiz harcamaları ve zorunlu harcamalardan oluşmaktaysa indeks değeri 0 olmaktadır. Sifır değer, kamu harcamalarında esneklik olmamasını ve bütçelemenin gelecek yıllardaki zorunlu kamu harcamalarının bir göstergesi olduğunu ifade etmektedir (Schiavo-Campo, 2017: 122). Mali demokrasi indeksinin negatif olmas1, mevcut gelirlerden daha fazlasının zorunlu harcama programlarına tahsis edildiği anlamına gelmektedir (Genschel ve Schwarz, 2012). Bir diğer ifade ile endeksin değeri ne kadar düşükse, mali kaynakların esnekliği o kadar düşük olmaktadır. Negatif bir değer, vergi gelirinin zorunlu harcamaları karşılamaya yeterli olmadığını ve hükümetin isteğe bağlı harcamalar için kullanılabilir kaynağı olmadığını göstermektedir (Roženský, 2012: 57). Endeksin pozitif değer alması ise zorunlu harcamalardan arta kalan ve isteğe bağlı harcamalar için kullanılabilecek kaynak olduğunu ve güncel karar merciinin kararlarına göre şekillenebilecek harcama kompozisyonunun oluşturulabileceğini göstermektedir.

Steuerle-Roeper mali demokrasi indeksinin altında yatan temel ayrım, tahsis edilmiş (uzun yıllardır yapılan, geçmişten gelen) ve tek kullanımlık (güncel kararlarla yapılan) devlet harcamaları veya zorunlu ve ihtiyari devlet harcamaları arasındadır (Streeck ve Mertens, 2010: 6). $\mathrm{Bu}$ açıdan herhangi bir ülke için geçerli mali demokrasinin oluşturulması, söz konusu ülke için zorunlu harcamaların belirlenmesini gerektirmektedir. Ancak her ülke için zorunlu harcamalar farklılaşabilmektedir. Bu anlamda Steuerle (2012: 149)'a göre, farklı ülkelerde, elbette, farklı yasal gelenekler, "zorunlu kılınan" harcamaların farklı yorumlarını gerektirmektedir.

İndeksin ilk olarak Steuerle tarafından ABD için oluşturulduğu göz önüne alındığında indeksin sadece ihtiyari harcamaların oylandığı ABD için operasyonel hale getirilmesi oldukça kolaydır. ABD'de zorunlu harcamalar, yasama organı kararlarının ötesinde gerçekleşen olaylardan kaynaklandığı için, oylanmamaktadır. Özellikle sosyal güvenlik veya işsizlik sigortası harcamaları, ya da federal sağlı programları olan Medicare ve Medicaid altındaki tıbbi bakım maliyetleri zorunlu harcamalar olarak görülmektedir. Ancak, tüm harcama kalemlerinin oylandığı Almanya için durum farklıdır. Bu nedenle örneğin Streeck ve Mertens (2010: 8), zorunlu harcama kalemlerini Almanya için yapılması yasal olarak zorunlu olan harcamalardan oluşturmuştur.

\section{ZORUNLU (KATI) HARCAMALAR KAVRAMI}

Zorunlu veya direkt harcamalar, özellikle ABD için söz konusu olan temel bir ayrımdır. Buna göre, zorunlu harcamalar-ihtiyari harcamalar ayrımı, ABD'de ilk olarak 1990 Bütçe Uygulama Kanunu ile yürürlüğe girmiş ve halen devam etmektedir (Ippolito, 2003: 8). Buna göre zorunlu harcamalar, kanunlarla kontrol edilen kamu harcamalarını kapsamaktadır. ABD zorunlu harcamalarının kapsamına vatandaşların daha önceden hak kazandığı sosyal güvenlik ödemeleri ve Medicare gibi sağlı harcamaları girmektedir (Austin ve Levit, 2012: 1). AB tarafindan yapılan ve 1982 tarihli Birleşik Deklarasyon'da ilan edilen tanıma göre zorunlu harcamalar, anlaşma ve yasalara uygun olarak, içsel ve dışsal biçimde halkın yükümlülüklerinin yerine getirmesini sağlamak üzere bütçe otoritesinin bütçeye koymak zorunda olduğu harcamalardır (Allen ve Tommasi, 2001: 96). Meklin vd. (2000:200-201)'e göre, zorunlu harcamalar, geçmiş y1llardaki kararlar sonucu otomatik olarak belirlenen, kontrol edilemeyen veya yapışkan harcamalar olarak tanımlanmıştır. Diğer yandan, zorunlu harcamalar, periyodik ödeneklerden ziyade, yasalarda belirtilen formül veya kriterlere göre yönetilen harcamalardır. Bu nedenle, açıkça değiştirilmediği sürece, önceki yılın harcaması, cari yıl için geçerlidir. Buna karşıllık, isteğe bağlı harcama, yıllık veya diğer dönemsel ödeneklerle yönetilen harcamalardır (Bowen vd., 2014: 2941). Bir diğer tanıma göre, zorunlu harcamalar, kamu harcamalarının her yıl oylanmayan, yani yasama organının herhangi bir işlemine bakılmaksızın otomatik olarak 
yapılan kısmıdır. Zorunlu programlardan yararlananlar, söz konusu programlara ilişkin hakları var olduğu sürece yasal olarak belirli bir miktar para veya hizmet alma hakkına sahiptir. Bu harcama her yıl yapılmalıdır ve bunları azaltmanın veya ortadan kaldırmanın tek yolu kanunu değiştirmektir. Burada, zorunlu harcamaların sinırlandırılabileceğini, ancak bu tür bir değişikliğin zor ve aynı zamanda uzun yasal süreçlerle bağlantılı olduğunu vurgulamak önemlidir (Roženský, 2011: 133-134). Bu anlamda kısa vadede zorunlu harcamalar tamamen katıdır (Kraan, 1984: 415).

ABD için yapılan bir araştırmaya göre, esnek olmayan veya zorunlu harcamalar dört kategoride ele alınmaktadır. İlk kategori, sosyal güvenliği de içeren güven fonlarıdır. Bu fonlara sürekli ödenek tahsis edilmekte ve fonlar bütçe yılı içinde kontrol edilmemektedir. İkinci sırada sürekli ve belirsiz ödenekler vardır. Sürekli ödeneklerin en güzel örneği, kamu faiz ödemeleridir. Belirsiz ödeneklere ise kamu çalışanlarına sosyal güvenlik katkısı örneği verilebilmektedir. Belirsiz ödeneklerde, yararlanıcı tarafından özel olarak tanımlanmış koşullar yerine getirilirse, bir devlet dairesinin gerekli bir miktarı harcamasına izin verilmektedir. Üçüncü kategori, harcama seviyeleri bütçe sürecinde değil kanunlarda tanımlanan programların neden olduğu sabit giderlerden oluşmaktadır. Bu kategorideki en büyük program, emeklilik ödemeleri ve gazilik yardımlarından oluşmaktadır. Dördüncü kategori, kısmi olarak tamamlanmış yatırımlardır. Bunun güzel bir örneği, gerçekleştirilmesi birkaç yıl süren ve projenin maliyetleri nedeniyle ekonomik olarak yarım bırakılması gereken inşaat projeleridir (Meklin vd., 2000:201). Diğer yandan ABD için Steuerle (2014) zorunlu harcamaları, sağlık harcamaları, sosyal güvenlik harcamaları, net faiz ödemesi ve diğer zorunlu harcamalar olarak belirtirken; Streeck ve Mertens (2010:32-35), Almanya için zorunlu kamu harcamalarını Nazi mağdurlarına yapılan ödemeler, kamu personeline yapılan ödemeler, Sosyal Güvenlik Fonlarına yapılan yardım ve transferler, işsizlik ödemeleri ve faiz ödemeleri olarak belirtmiştir. Francesco (2012:6), OECD ülkeleri için zorunlu kamu harcamalarını, kamu personeli ücret ödemeleri ve sosyal güvenlik ödeme ve transferleri (işsizlik ücretini de içerir) olarak belirlemiştir. Sonuç olarak, zorunlu harcamalar ülkeden ülkeye farklılaşan içerikler ihtiva etmekle birlikte, literatüre göre zorunlu harcamalar genel olarak sosyal güvenlik harcamaları, faiz servisi ve ücret ödemelerinden oluşmaktadır (Muñoz ve Olaberria, 2019: 3; Fay ve Rodgers, 2008: 2; Abdellatif vd., 2019: 53; Allen ve Tommasi, 2001: 80).

Zorunlu harcamaların varlığı ülke ekonomisi ve diğer yandan maliye politikası için önemli sonuçlar doğurmaktadır. Nitekim zorunlu harcamalar sonucu oluşan harcama katılı̆̆ nedeniyle hükümet maliye politikası üzerindeki kontrolünü kaybedebilmektedir. Ülke gerekli durumlarda harcamaları yeterince kısamadığından mali alan daralmakta ve yeni ve önemli programlara kaynak aktaramamaktadır. Örneğin, zorunlu harcamalar nedeniyle mali düzenlemeler genellikle sermaye harcamalarının düşürülmesine odaklanmaktadır (Barbados'ta bu durum yaşanmıştır). Bu anlamda, zorunlu harcamalar büyük ölçüde arttığında, eğitimin iyileştirilmesi, bilimsel araştırmaların finansmanı, yol yapımı, hastanelerin modernizasyonu ve diğer yatırım türleri gibi ülkenin kalkınması için önemli olan harcamaları karşılayacak çok az kaynak kalmaktadır. Bu durum herhangi bir hükümetin öncelikli projelerine ulaşmasını ve maliye politikasının tahsis (kaynakların dağılımı) esnekliğini engellemektedir (Itaborai, 2015: 3). $\mathrm{Bu}$ konuda Brazilya Hazinesi'ne göre: "Brezilya'da gelirleri artırmak çok zorken mali ayarlamalar yapmanın zorluğunun yanı sıra, zorunlu harcamalardaki büyüme ihtiyari harcamaları sınırlamaya devam ediyor" (Reuters, 2019).Yüksek zorunlu harcama sonucu oluşan harcama katılığı, ülkelerin mali krizleri çözme kabiliyetini olumsuz etkilemektedir. Bunun nedeni giderlerin yeterince kısılamamasıdır'.Zorunlu harcamalar ülkelerde mali stres

\footnotetext{
1 Bu konuda farklı görüşlere ulaşmak mümkündür. Örneğin, Levit vd. (2015: 1)’e göre, zorunlu harcamalar, konjonktüre karşı önemli bir rol oynamaktadır. Ekonomik daralma dönemlerinde, daha fazla insan işsizlik sigortası ve gelir güvencesi programları gibi zorunlu programlara hak kazandıkça devlet gelirleri düşmekte ve harcamalar
} 
yaşanmasına ve mali konsolidasyonun kısıtlı kalmasına yol açabilmektedir (Muñoz ve Olaberria 2019). Bu anlamda mali konsolidasyonun kalitesi etkilenmektedir. Çünkü bu durumlarda sermaye harcamaları kısılabilmekte, büyüme ve istihdam azalabilmektedir. Diğer yandan kaynak performansa dayalı olmadan garanti edildiğinde kamu harcamalarında etkinlik azalabilmektedir (IFS, 2017; Schmid vd., 2018: 9). Son olarak, kronik bütçe açıkları ve artan kamu borçları, giderek artan zorunlu harcamaların yaygın bir sonucudur. Gelirler yeterince arttırılamadığında katı harcamaların varlığı bütçe açıkları ve borçlanmayı beraberinde getirmektedir (Jamaika'da durum budur) (Schmid vd., 2018: 3; Abdellatif vd., 2019: 52).

\section{TÜRKIYYE'DE ZORUNLU HARCAMALAR}

Türkiye için zorunlu kamu harcamalarını belirlemek oldukça zordur. Nitekim zorunlu harcama kapsamında değerlendirilen savunma harcamaları da bütçe görüşmelerinde (Mecliste) oylanmaktadır. Bu anlamda Türkiye'de katı harcamalar olarak da sinıflandırılabilen (Çebi, 2015), zorunlu harcamalar belirlenirken, IMF tanımı (IMF, 2013: 32) temel alınmıştır. IMF'e göre Türkiye'de zorunlu harcamalar Sosyal Güvenlik Kurumu'na merkezi yönetim bütçesinden transfer edilen paylar, mahalli idarelere genel bütçeden aktarılan paylar, KİT'lere merkezi yönetimden yapılan sübvansiyonlar, cari (mal ve hizmet harcamaları) sağlık harcamaları ve personel giderleri olarak belirlenmiş̧ir. Bu zorunlu harcamalara Steuerle (2012)'yi dikkate alarak faiz ödemesi de eklenmiştir.

\subsection{Sosyal Güvenlik Kuruluşu'na Aktarılan Paylar}

Geçmişten günümüze bireyler risklere karşı kendilerini koruma güdüsüne sahiplerdir. $\mathrm{Bu}$ güdü zamanla devletlerin sosyal güvenlik ihtiyacına karşı harekete geçmesine ve sosyal güvenlik sistemi tesisine yol açmıştır. Bu bağlamda günümüzde bütün ülkeler belirli bir sosyal güvenlik sistemine sahiptir. Sosyal güvenliğin finansmanı ise son dönemlerde artan bir öneme sahiptir ve bu problemden Türkiye'de nasibini almıştır (Canbay ve Demir, 2013: 304).

Türkiye'de 1945 y1lından itibaren uygulamaya konulan sosyal güvenlik sisteminde 1985 yılına değin bir fazla söz konusu iken, bu tarihten sonra açık verilmeye başlanmıştır. Sonrasında artan sosyal güvenlik açıkları Türkiye'nin başlıca mali problemlerinden biri haline gelmiştir. Günümüzde sosyal güvenlik sisteminin açık vermesinin ardında birçok ekonomik, yönetsel ve demografik faktör yatmaktadır. Bu faktörlerin başında kayıt dışı istihdam ve tahsilat sorunları gibi nedenlerle yeterli düzeyde olmayan prim gelirleri gelmektedir. Ayrıca; emekli sayısı artışı, aktif/pasif sigortalı oranının düşük olması, emekliliğe hak kazanma yaşının düşük tutulması gibi birçok etken sosyal güvenlik açıklarını arttırmıştır.

Ekonomik sorunlar yanında yönetsel ve kurumsal yapılanma sorunları, fonların etkin kullanılmaması ya da enflasyon nedeniyle erimesi, prim affi uygulamaları ve bu uygulamaların vatandaşların beklentilerini olumsuz etkilemesi, prim tahsilatında yaşanan sorunlar ve denetim yetersizliği gibi nedenler kronikleşen açıklarının ardındaki temel faktörler olarak gösterilebilir (Gümüş, 2010: 16).

Sosyal Güvenlik Kuruluşunun (SGK) açık vermesi ile birlikte bu kuruluşa genel bütçeden pay aktarılmaktadır. Dolayısıyla dünyada yaşanan gelişmelere paralel olarak, Türkiye'de de sosyal güvenlik açıkları bütçeye yük olmaya devam etmektedir.

\footnotetext{
artmaktadır ki bu da açıkların artmasına neden olmaktadır. "Otomatik stabilizatörler" olarak bilinen bu etkiler, yeni yasal eyleme ihtiyaç duymadan kısa vadede konjonktür karşıtı bir mali teşvik sağlamaktadır. Diğer yandan Bowen vd. (2014)'ün bulgusuna göre, zorunlu programlar hükümet ve muhalefet partilerinin pazarlık gücünü etkilemekte ve yetersiz kamu mal ve hizmeti sunumunu önlemektedir.
} 
Sosyal güvenlik açıklarını azaltmaya yönelik özellikle 2006 yılından itibaren bazı tedbirler alınmaya başlanmıştır. Bu kapsamda yapılan reformlardan bazıları ise, emeklilik yaşının kademeli olarak arttırılması, prim ödeme gün sayısının yükseltilmesi ve prim ödemelerinin daha sık1 takip ve denetimidir (Şahin, 2016: 613-614). Bununla beraber, SGK'ya genel bütçeden aktarılan paylarda bir iyileşme yaşanmamış, aksine 2008 yılında sosyal güvenlik primlerine ve işveren paylarına yapılan devlet katkısı, giderleri daha da arttırmıştır (Canbay ve Demir, 2013: 308).

Tablo 1: Sosyal Güvenlik Kurumuna Genel Bütçeden Aktarılan Paylar ve Gelirlerin Giderleri Karşılama Oranı (2010-2019)

\begin{tabular}{lccc}
\hline Yıllar & $\begin{array}{c}\text { Sosyal Güvenlik Kurumuna } \\
\text { Bütçeden Aktarılan Paylar } \\
\text { (Reel, Milyon TL)* }\end{array}$ & $\begin{array}{c}\text { Sosyal Güvenlik Kurumuna } \\
\text { Bütçeden Aktarlan } \\
\text { Paylar/GSYH (\%) }\end{array}$ & $\begin{array}{c}\text { Sosyal Güvenlik Kurumuna } \\
\text { Bütçeden Aktarılan Paylar/Merkezi } \\
\text { Yönetim Harcamaları (\%) }\end{array}$ \\
\hline 2010 & 51.432 & 4,7 & 18,7 \\
\hline 2011 & 45.634 & 3,8 & 16,8 \\
\hline 2012 & 51.179 & 4,1 & 17,6 \\
\hline 2013 & 54.323 & 4,0 & 17,6 \\
\hline 2014 & 54.444 & 3,8 & 17,2 \\
\hline 2015 & 52.314 & 3,4 & 15,8 \\
\hline 2016 & 64.532 & 4,1 & 18,3 \\
\hline 2017 & 72.144 & 4,3 & 19,5 \\
\hline 2018 & 69.406 & 4,0 & 17,9 \\
\hline 2019 & 80.905 & 4,6 & 19,7 \\
\hline
\end{tabular}

Kaynak: Hazine ve Maliye Bakanlığ1, 2020a, 2020b'dan yararlanılarak hazırlanmıştır.

*Reel değer, ilgili nominal değerlerin Dünya Bankası (2020)'ndan alınan Türkiye GSYH Deflatörüne bölünmesi sonucu elde edilmiştir.

Tablo 1'de sosyal güvenlik kuruluşlarına genel bütçeden yapılan transferler (reel) verilmiştir. Tablo'ya göre sosyal güvenlik kuruluşlarına genel bütçeden yapılan transferler genel olarak artış trendindedir. Buna göre 2010 yılında 51.432 milyon TL olan transferler, 2019 yılında 80.905 milyon TL'ye yükselmiştir. Şüphesiz nominal olarak hızla artan transferler, enflasyonun etkisi çıkartıldığında (deflate-reel) daha yavaş artmıştır.

Genel bütçeden sosyal güvenlik kuruluşuna yapılan transferlerin GSYH içindeki payına bakıldığında söz konusu oranın dalgalı bir seyir izlediği görülmektedir. Sosyal güvenlik kuruluşuna transfer edilen payın merkezi yönetim harcamalarına oranına bakıldığında ise trendin çok değişmediği göze çarpmaktadır. 2010 yılında \%18,7 olan oran yıllar itibariyle dalgalı seyir göstermiş, 2019 yılında \%19,7 olarak gerçekleşmiştir. Bu gösterge bütçe harcamalarındaki artışın SGK'ya yapılan transferlerle benzer yapı taşıdığını göstermektedir.

\subsection{Mahalli İdarelere Aktarılan Paylar}

Mahalli idarelerin gelir ve harcama farklılıklarını kapatma yanında idarelere verilen görev ve fonksiyonları etkin şekilde gerçekleştirmeleri amacıyla genellikle merkezi idarelerden mahalli idarelere mali transferler gerçekleştirilmektedir (Ulusoy ve Demir, 2018: 264). Dünyadaki uygulamalara benzer şekilde Türkiye'de de merkezi yönetimden mahalli idarelere 
mali transferler yapılmakta ve bu transferler temel bazı kanunlara dayandığından zorunlu (katı) olarak addedilmektedir.

Türkiye'de merkezi idareden mahalli idarelere mali transferler üç yolla yapılmaktadır. Bunlardan ilki mahalli idarelere genel bütçe vergi gelirlerinden pay verilmesi; ikincisi genel ve özel bütçeli idarelerden yapılan ödemeler (5779 sayılı Kanun ile birlikte sadece denkleștirme ödeneği), üçüncüsü ise merkezi yönetime dahil kurum ve kuruluşlardan yapılan bağış ve yardımlardır.

Konumuz itibari ile merkezi idarenin kanunen yapmak zorunda olduğu harcamalar belirli kanuni zorunluluk çerçevesinde yapılması gereken harcamalardır (IMF, 2013: 1-32). Bu anlamda zorunlu harcamalar, genel bütçe vergi gelirlerinden aktarılan paylar ve belediyelere yapılan denkleştirme ödeneğinden oluşmaktadır. Bunun nedeni her iki ödemenin de 5779 sayılı Kanun ile hüküm altına alınmış olmasıdır. Şöyle ki, genel bütçe vergi gelirlerinden aktarılan paylar 2008 yılına kadar 2380 sayılı Kanun çerçevesinde verilmiştir. 2008 y1lında çıkarılan 5779 sayılı İl Özel İdarelerine ve Belediyelere Genel Bütçe Vergi Gelirlerinden Pay Verilmesi Hakkındaki Kanun ve 6360 sayılı Kanun ile genel bütçe vergi gelirlerinden aktarılan pay oranlarında değişiklik yapılmıştır. Söz konusu Kanunlar ile yapılan son düzenlemelere göre genel bütçe vergi gelirleri tahsilatının \%1,50'si büyükşehir dışındaki belediyelere ayrılmaktadır. Burada bahsedilen belediyeler büyükşehir dışında kalan 51 il belediyesi ile bu illerdeki ilçe ve belde belediyelerinden oluşmaktadır. Diğer yandan genel bütçe vergi gelirleri tahsilatının $\% 4,50$ 'si büyükşehirlerdeki ilçe belediyelerine aktarılmaktadır. Genel bütçe vergi gelirleri tahsilatı toplamının \%0,50'si ise il özel idarelerine aktarılmaktadır.

Yine, 4760 sayılı Özel Tüketim Vergisi Kanunu'na ekli (I) sayılı listede yer alan mallardan tahsil edilen özel tüketim vergisi hariç olmak üzere, büyükşehir belediyesi sınırları içinde yapılan genel bütçe vergi gelirleri tahsilatı toplamının \%6's1 ile genel bütçe vergi gelirlerinden büyükşehirlerdeki ilçe belediyelerine aktarılan payın \%30'u büyükşehir belediye payı olarak ayrılmaktadır.

5779 sayılı Kanun ile yerel yönetimlerin mali kapasitelerinin güçlendirilmesi, merkezi yönetimden mahalli idarelere yapılan yardımların dağınıklığının giderilmesi ve yerel yönetimlerin gelir ve harcama kapasitelerinin dengelenmesi amacıyla Bakanlıkların ve diğer kamu kurum ve kuruluşlarının yerel yönetimlere yardım amacıyla bütçelerine ödenek konulamayacağı hüküm altına alınmıştır (Mutluer ve Öner, 2009: 183). Kaldırılan uygulama yerine 5779 sayılı Kanun ile denkleştirme ödeneği sistemi getirilmiştir. Buna göre kesinleşmiş en son genel bütçe vergi gelirleri tahsilatının binde 1'inin Hazine ve Maliye Bakanlığı bütçesine, nüfusu 10.000'e kadar olan belediyelere aktarılmak üzere "denkleştirme ödeneği” olarak konulması esası getirilmiştir. Hazine ve Maliye Bakanlığı bu ödeneği mart ve temmuz aylarında iki eşit taksitte dağıtılmak üzere, İller Bankası hesabına aktarmakta ve İller Bankası da hesabına aktarılan ödeneğin \%65'ini eşit şekilde, \%35'ini ise nüfus esasına göre dağıtmaktadır.

Diğer yandan merkezi yönetim kuruluşlarınca mahalli idarelere verilen bağışlar ise ihtiyari veya zorunlu olabilmektedir (Ulusoy ve Akdemir, 2017: 304). Dolayısıyla bağışlar kimi zaman belirli kanunlarda ayrıntılı olarak düzenlenmiş iken, kimi zaman da bu konuda belirli bir kanun bulunmamaktadır. Bu nedenle bağışları zorunlu harcama olarak değerlendirmek mümkün değildir. 
Tablo 2: Genel Bütçe Vergi Gelirleri Tahsilatı Üzerinden Mahalli İdarelere Verilen Paylar ve Denkleștirme Ödeneğine İlişskin Göstergeler (2010-2019)

\begin{tabular}{|c|c|c|c|c|}
\hline Yıllar & $\begin{array}{c}\text { Genel Bütçe Vergi } \\
\text { Gelirleri Tahsilatı } \\
\text { Üzerinden Mahalli } \\
\text { İdarelere Verilen Paylar } \\
\text { (Reel, Milyon TL)* }\end{array}$ & $\begin{array}{c}\text { Genel Bütçe Vergi Gelirleri } \\
\text { Tahsilatı Üzerinden } \\
\text { Mahalli İdarelere Verilen } \\
\text { Payların Vergi Gelirlerine } \\
\text { Oranı (\%) }\end{array}$ & $\begin{array}{c}\text { Denkleştirme } \\
\text { Ödeneği (Reel, } \\
\text { Milyon TL)* }\end{array}$ & $\begin{array}{c}\text { Denkleştirme } \\
\text { Ödeneği/Mahalli } \\
\text { İdarelere Yapılan } \\
\text { Zorunlu Transferler } \\
(\%)\end{array}$ \\
\hline 2010 & 19.614 & 8,9 & 158 & 0,81 \\
\hline 2011 & 21.689 & 8,8 & 149 & 0,68 \\
\hline 2012 & 22.555 & 8,8 & 168 & 0,75 \\
\hline 2013 & 24.799 & 8,9 & 144 & 0,58 \\
\hline 2014 & 27.774 & 9,8 & 205 & 0,74 \\
\hline 2015 & 30.419 & 10,0 & 214 & 0,70 \\
\hline 2016 & 31.787 & 9,9 & 256 & 0,81 \\
\hline 2017 & 33.539 & 9,8 & 308 & 0,92 \\
\hline 2018 & 33.800 & 9,8 & 340 & 1,01 \\
\hline 2019 & 31.399 & 9,3 & 220 & 0,70 \\
\hline
\end{tabular}

Tablo 2'de genel bütçe vergi gelirleri tahsilatı üzerinden mahalli idarelere verilen paylar ve denkleştirme ödenekleriyle ilgili bazı rasyolar gösterilmiştir. 2010 yılı itibariyle mahalli idarelere aktarılan pay 19.614 milyon TL'dir. Söz konusu pay, 2019 yılı itibariyle reel olarak 31.399 milyon TL olarak gerçekleşmiştir. Genel bütçe vergi gelirleri tahsilatı üzerinden mahalli idarelere verilen payların vergi gelirlerine oranı ise 2010 'da \%8,9 olarak gerçekleşmiştir. Söz konusu payın 2019 itibariyle \%9,3 olarak gerçekleşmesi, payın vergi gelirleriyle paralel seyrettiğini göstermektedir.

Tablo 2'de denkleştirme ödeneğinin seyri de yer almaktadır. 2010 yılında 158 milyon TL olarak gerçekleşen ödenek, 2018 yılında 340 milyon TL'ye ulaşmış ve 2019 yılı itibari ile azalış göstererek 220 milyon TL olarak gerçekleşmiştir. Denkleştirme ödeneğinin mahalli idarelere yapılan zorunlu transferler içindeki payı ise genel bütçe vergi gelirlerindeki dalgalanmaya paralel olarak yıllar itibariyle dalgalı bir seyir izlemiştir. 2010-2019 döneminde $\% 1,01$ ile $\% 0,7$ arasında değerler almıştır.

\subsection{Kamu İktisadi Teşebbüslerine Aktarılan Paylar}

Kamu iktisadi teşebbüslerine (KIT) ilişkin tek bir tanım yapmak oldukça zordur. Nitekim, Anayasa'da, 3346 sayılı KİT'lerin TBMM'ce Denetlenmesine İlişkin Yasa'da ve KIT'leri düzenleyen 233 sayılı KHK'da farklı kamu iktisadi teşebbüsü tanımları yapılmıştır (Öztürk, 2018: 199). Bunlardan Anayasa'nın 165'inci maddesinde "Sermayesinin yarısından fazlası doğrudan doğruya veya dolaylı olarak devlete ait olan kamu kuruluş ve ortaklıkları...", KİT olarak tanımlarken 233 sayılı Kamu İktisadi Teşebbüsleri Hakkında Kanun Hükmünde Kararname söz konusu tanımı daha ayrıntılı olarak ele almıştır. 233 sayılı KHK'ya göre KİT'ler Kamu İktisadi Kuruluşları (KİK) ve İktisadi Devlet Teşekküllerinden (IDT) oluşmaktadır. 233 sayılı KHK' da KİK, "Sermayesinin tamamı devlete ait olup tekel niteliğindeki mal ve hizmetleri kamu yararı gözeterek üretmek ve pazarlamak üzere kurulan ve gördüğü bu kamu hizmeti 
dolayısıyla ürettiği mal ve hizmetler imtiyaz sayılan kamu iktisadi teşebbüsüdür" olarak tanımlamaktadır. IDT ise "Sermayesinin tamamı devlete ait, iktisadi alanda ticari esaslara göre faaliyet göstermek üzere kurulan, kamu iktisadi teşebbüsüdür" olarak tanımlanmıştır.

Kamu iktisadi teşebbüsleri ile merkezi idarenin mali ilişkisi günümüzde azalmakla birlikte genellikle merkezi yönetim bütçesinden KİT'lere kaynak transferi şeklinde olmuştur. Yasal dayanağını 233 sayılı KHK ve KİT'lere görev veren Bakanlar Kurulu Kararlarından alan (Ayyıldız Sayın, 2005a: 96) söz konusu kaynak transferi iki şekilde yapılmaktadır. Birisi; merkezi yönetim bütçesinden KİT'lere yapılan sermaye transferi ve diğeri Bakanlar Kurulu tarafindan KİT'lere verilen görevler sonucunda oluşan zararlara karşıl1k yapılan ödemelerden oluşmaktadır. KİT'lere verilen görevler çerçevesinde ortaya çıkan zarar ile mahrum kalınan kârın toplamı olarak tanımlanan görev zararı yine merkezi yönetimden yapılan transferlerle karşılanmaktadır (Hazine ve Maliye Bakanlığı, 2017: 10-12). Görev zararı nedeniyle merkezi yönetimden yapılan transferlerin bir diğer tanımlanma şekli sübvansiyonlardır (Ayyıldız Sayın, 2015b: 180). KİT'lere verilen sübvansiyonlar ise konumuz itibariyle zorunlu harcamalar sinifindadir.

Tablo 3: Merkezi Yönetim Bütçesinden KİT'lere (Özelleştirme Kapsamındakiler Dahil) Yapılan Sübvansiyonlar (2010-2019)

\begin{tabular}{|c|c|c|}
\hline Yillar & $\begin{array}{c}\text { Merkezi Yönetim Bütçesinden KİT'lere } \\
\text { Yapılan Sübvansiyonlar (Reel, Milyon TL)* }\end{array}$ & $\begin{array}{c}\text { Merkezi Yönetim Bütçesinden KİT’lere Yapılan } \\
\text { Sübvansiyonlar/Merkezi Yönetim Harcamaları } \\
(\%)\end{array}$ \\
\hline 2010 & 1.481 & 0,54 \\
\hline 2011 & 2.185 & 0,80 \\
\hline 2012 & 1.522 & 0,52 \\
\hline 2013 & 1.232 & 0,40 \\
\hline 2014 & 1.235 & 0,39 \\
\hline 2015 & 1.465 & 0,44 \\
\hline 2016 & 1.523 & 0,43 \\
\hline 2017 & 1.849 & 0,50 \\
\hline 2018 & 1.018 & 0,26 \\
\hline 2019 & 686 & 0,17 \\
\hline
\end{tabular}

Tablo 3'te merkezi yönetim bütçesinden KìT'lere verilen sübvansiyonlar (reel) yer almaktadır. Tablo 3'e göre merkezi yönetim bütçesinden KİT'lere verilen sübvansiyonlar dalgalı bir seyir izlemektedir. Nitekim 2010 y1lında 1.481 milyon TL olan sübvansiyonlar, 2017 yılında 1.849 milyon TL'ye kadar ulaşmış, sonrasında ise azalmaya başlamıştır. 2019 yılında 686 milyon TL'ye düşerek incelenen dönemde en düşük payı almıştır. Merkezi yönetim bütçesinden KİT'lere verilen sübvansiyonların merkezi yönetim harcamalarına oranı ise genel olarak düşüş eğilimi göstermiştir. Nitekim 2010 y1lında \%0,54 olan söz konusu oran 2019 y1lında \%0,17'ye gerilemiştir. 


\subsection{Sağlık Harcamaları (Cari)}

Zorunlu harcamalardan bir diğeri ise sağlık konusunda yapılan mal ve hizmet harcamalarıdır. Cari harcamalar olarak değerlendirilebilecek olan bu harcamalar içerisinde tıbbi malzeme alımı, evde hemşirelik bakımı, genel hastane hizmetleri gibi mal ve hizmetlere yönelik harcamalar bulunmaktadır. Tablo 4'te merkezi yönetimce yapılan cari sağlık harcamalarına yer verilmiştir.

Tablo 4: Merkezi Yönetim Bütçesinden Yapılan Cari Sağlık Harcamaları (2010-2018)

\begin{tabular}{|c|c|c|}
\hline Yillar & $\begin{array}{c}\text { Merkezi Yönetim Bütçesinden Yapılan } \\
\text { Cari Sağlık Harcamaları (Reel, Milyon } \\
\text { TL)* }\end{array}$ & $\begin{array}{l}\text { Merkezi Yönetim Bütçesinden Yapılan Cari Sağlık } \\
\text { Harcamaları /Merkezi Yönetim Harcamaları (\%) }\end{array}$ \\
\hline 2010 & 14.304 & 5,2 \\
\hline 2011 & 14.882 & 5,5 \\
\hline 2012 & 11.631 & 4,0 \\
\hline 2013 & 11.866 & 3,8 \\
\hline 2014 & 12.829 & 4,1 \\
\hline 2015 & 13.238 & 4,0 \\
\hline 2016 & 14.679 & 4,2 \\
\hline 2017 & 15.083 & 4,1 \\
\hline 2018 & 15.916 & 4,1 \\
\hline
\end{tabular}

Tablo 4'e göre merkezi yönetim bütçesinden yapılan cari sağlık harcamaları (reel) genel bir artış trendinde seyretmiş̧tir. 2010 yılında 14.304 milyon TL olarak gerçekleşen cari sağlık harcamaları 2018 yılında 15.916 milyon TL olarak gerçekleşmiştir. Merkezi yönetim bütçesinden yapılan cari sağlı harcamalarının merkezi yönetim harcamaları içindeki payına bakıldığında ise, $\% 4$ civarında stabil kaldığı görülmektedir.

\subsection{Personel Ücret Giderleri}

Personel harcamaları, merkezi yönetim bütçesi içindeki zorunlu harcamalardan bir diğeridir. Personel giderleri gerek mahalli idarelerde ve gerekse merkezi yönetimde bütçenin önemli bir bölümünü teşkil etmektedir. Merkezi yönetim bütçesi içinde personel giderleri yıllar itibariyle artmıştır. Bu artışın önemli bir kısmının personel sayısı ve personel maaşlarındaki artıştan kaynaklandığı söylenebilir (BÜMKO, 2020). Tablo 5 'te görülebileceği gibi tüm yıllarda personel giderlerinin merkezi yönetim giderleri içindeki payı \%21-25 aralığında seyretmiştir. 
Tablo 5: Merkezi Yönetim Bütçesinden Yapılan Personel Ücret Giderleri (2010-2019)

\begin{tabular}{|c|c|c|}
\hline Yillar & $\begin{array}{l}\text { Merkezi Yönetim Personel Giderleri } \\
\text { (Reel, Milyon TL)* }\end{array}$ & $\begin{array}{l}\text { Merkezi Yönetim Personel Giderleri } \\
\text { /Merkezi Yönetim Harcamaları }(\%)\end{array}$ \\
\hline 2010 & 58.231 & 21,2 \\
\hline 2011 & 62.979 & 23,2 \\
\hline 2012 & 69.524 & 23,9 \\
\hline 2013 & 72.817 & 23,6 \\
\hline 2014 & 77.743 & 24,6 \\
\hline 2015 & 81.690 & 24,7 \\
\hline 2016 & 89.960 & 25,5 \\
\hline 2017 & 88.309 & 23,9 \\
\hline 2018 & 93.969 & 24,2 \\
\hline 2019 & 102.587 & 25,0 \\
\hline
\end{tabular}

\subsection{Faiz Giderleri}

Borçların faiz ödemeleri, belirli bir faiz oranından ve vadesi geldiğinde yapılmaktadır. Son yıllarda kamu borç stoku artmasına rağmen GSYH'ye oranla makul seviyelerde kalması sonucu faizlerde yaşanan gerileme, faiz servisinin bütçe giderleri içindeki payını azaltmıştır. Nitekim Türkiye'de 2010-2017 döneminde faiz servisi (giderleri) genel olarak azalan bir seyir izlemiştir. Tablo 6'ya bakıldığında merkezi yönetim faiz giderleri 2017 yılına kadar reel olarak düşmüş, sonrasında artış trendine girmiştir. 2010 yılında 45.134 milyon TL olan reel faiz ödemeleri 2016 yılında 30.365 milyon TL'ye kadar düşmüş, sonrasında artış trendine girerek 2019 yılında 41.030 milyon TL'ye ulaşmıştır. Burada hiç şüphesiz 2018 yılının ortalarında başlayan kur şoku ve onun neden olduğu makro dengelerdeki bozulmanın faiz artışlarına etkisi vardır.

Merkezi yönetim faiz giderlerinin merkezi yönetim harcamaları içindeki payı ise söz konusu yıllarda sürekli düşmüştür. Bu sonuçta hiç şüphesiz faiz giderlerinde 11 เmlı artış ile birlikte faiz dışı harcamaların daha hızlı artmasının etkisi vardır. 2018-2019 döneminde ise 1lımlı şekilde artan söz konusu pay 2019 y1lında \%10 olarak gerçekleşmiştir. 
Tablo 6: Merkezi Yönetim Bütçesinden Yapılan Faiz Giderleri (2010-2019)

\begin{tabular}{|c|c|c|}
\hline Yillar & $\begin{array}{c}\text { Merkezi Yönetim Faiz Giderleri } \\
\text { (Reel, Milyon TL)* }\end{array}$ & $\begin{array}{c}\text { Merkezi Yönetim Faiz Giderleri /Merkezi Yönetim } \\
\text { Harcamaları (\%) } \\
\end{array}$ \\
\hline 2010 & 45.134 & 16,4 \\
\hline 2011 & 36.478 & 13,4 \\
\hline 2012 & 38.931 & 13,4 \\
\hline 2013 & 37.822 & 12,2 \\
\hline 2014 & 35.158 & 11,1 \\
\hline 2015 & 34.625 & 10,5 \\
\hline 2016 & 30.365 & 8,6 \\
\hline 2017 & 30.887 & 8,4 \\
\hline 2018 & 34.594 & 8,9 \\
\hline 2019 & 41.030 & 10,0 \\
\hline
\end{tabular}

\section{TÜRKIYYE'DE MALİ DEMOKRASİ İNDEKSİ}

Mali demokrasi indeksini hesaplayabilmek için kamu gelirlerinden öncelikle zorunlu kamu giderlerinin çıkarılması ve bulunan tutarın toplam kamu gelirlerine oranlanması gerekmektedir. Türkiye için merkezi yönetim zorunlu harcamalarına bakıldığında (Tablo 7) yıllar itibari ile artış süreci göze çarpmaktadır. Nitekim 2010 yılında 190.354 milyon TL olan zorunlu harcamalar, reel olarak da artarak 2019 yılında 273.035 milyon TL'ye ulaşmıştır. Benzer şekilde merkezi yönetim gelirleri (tahsilat) de sürekli artmıştır. Nitekim 2010 y1lında 229.927 milyon TL olan gelirler, 2019 yılında 350.259 milyon TL olarak gerçekleşmiştir.

Tablo 7:Merkezi Yönetim Zorunlu Harcamaları ve Toplam Gelirlerine İlişkin Göstergeler (2010-2019)

\begin{tabular}{ccccc}
\hline Yıllar & $\begin{array}{c}\text { Merkezi Yönetim } \\
\text { Zorunlu } \\
\text { Harcamaları (Reel, } \\
\text { Milyon TL)* }\end{array}$ & $\begin{array}{c}\text { Merkezi Yönetim } \\
\text { Gelirleri (Reel, } \\
\text { Milyon TL)* }\end{array}$ & $\begin{array}{c}\text { Merkezi Yönetim Gelirleri - } \\
\text { Merkezi Yönetim Zorunlu } \\
\text { Harcamalar (Reel, Milyon } \\
\text { TL)* }\end{array}$ & $\begin{array}{c}\text { Merkezi Yönetim } \\
\text { Gelirleri-Zorunlu } \\
\text { Harcamalar) / Merkezi } \\
\text { Yönetim Gelirleri (\%) }\end{array}$ \\
\hline 2010 & 190.354 & 229.927 & 39.573 & 17,2 \\
\hline 2011 & 183.996 & 247.508 & 63.512 & 25,7 \\
\hline 2012 & 195.510 & 259.906 & 64.396 & 24,8 \\
\hline 2013 & 203.003 & 285.519 & 82.516 & 28,9 \\
\hline 2014 & 209.388 & 289.472 & 80.084 & 27,7 \\
\hline 2015 & 213.965 & 304.859 & 90.894 & 29,8 \\
\hline 2016 & 233.102 & 324.070 & 90.968 & 28,1 \\
\hline 2017 & 242.119 & 332.361 & 90.242 & 27,2 \\
\hline 2018 & 249.043 & 342.569 & 93.526 & 27,3 \\
\hline 2019 & 273.035 & 350.259 & 77.224 & 22,0 \\
\hline
\end{tabular}

Kaynak:(Hazine ve Maliye Bakanlığı, 2020c).

Not: 2019 yılı cari sağlık harcamaları verileri TÜIK tarafindan açıklanmadı̆̆ından 2019 yılı için cari sağlık harcamamaları ortalama artış oranına göre oluşturulan veriler kullanılmıştır. 
Tablo 7'de zorunlu harcamaların karşılığ ayrıldıktan sonra merkezi yönetim gelirlerinden arta kalan gelirler gösterilmiştir. Söz konusu verilere göre mali demokrasi indeksine temel oluşturan artık gelirlerde dalgalı bir seyir göze çarpmaktadır. Nitekim 2010'da 39.573 milyon TL'ye, 2015 y1lında 90.894 milyon TL'ye ve 2019 y1lı itibari ile 77.224 milyon TL'ye ulaşan artık gelir, 2011-2013 döneminde artmış ve 2014 yılında düşerek 80.084 milyon TL'ye ulaşmıştır. Ardından stabil bir seyir görülmüştür. 2019 yılında ise artık gelirde önemli bir daralma söz konusudur.

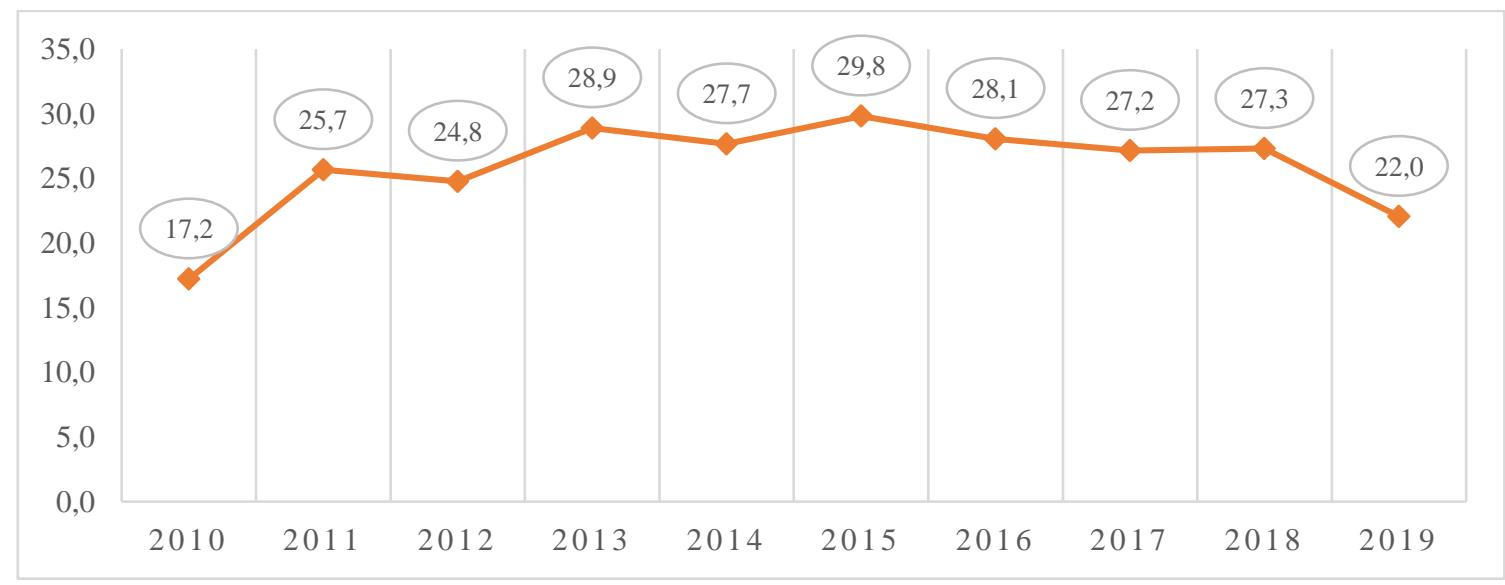

Grafik 1:Türkiye İçin Mali Demokrasi İndeksi (\%)

Kaynak: Yazarlar tarafından oluşturulmuştur.

Grafik 1'de Türkiye için mali demokrasi indeksi görülmektedir. Grafikte indeksin incelenen dönemde pozitif olduğu, fakat dalgalı bir seyir izlediği görülmektedir. Bu durum Türkiye ekonomisinde yaşanan konjonktürel dalgalanmaları yansıtmaktadır. İndeksin pozitif olması halk adına karar veren meclisin iradesiyle fon kullanması (harcama yapması) anlamına gelmektedir.

Diğer yandan, pozitif indeks Türkiye'de son y1llarda yaşanan gelişmelere 1 ş1k tutmaktadır. Nitekim gerek zorunlu kamu harcamaları ve gerekse vergi gelirleri ile doğrudan ilgili olan indeks bu iki parametredeki gelişmeleri yansıtmaktadır. Şöyle ki, incelenen dönemde vergi politikası belirli düzeyde gelir sağlama temel amacını realize etmede başarılı olmuş ve vergi gelirleri artmıştır. Yine, bu amaç doğrultusunda kayıt dışı ekonomi ile mücadele güçlendirilmiştir (Gelir Politikaları Genel Müdürlügü̈, 2017). Ayrıca, yüksek büyüme oranları nedeniyle de vergi gelirleri artmıştır. Bu durum kamu gelirleri içinde vergi gelirlerinin payını artırmıştır.

Zorunlu harcamaların da reel artış trendinde olduğu görülmektedir. Zorunlu harcamalar içinde mahalli idarelere aktarılan paylar, personel giderleri ve sosyal güvenlik kurumlarına yapılan transferlerin payı önemli düzeydedir.

Özetle; mali demokrasi indeks değerleri, ihtiyari kamu harcamaları için yeterli gelir elde edildiğini, maliye politikası alternatifleri için önemli seviyede bir mali alan oluşturulduğunu göstermektedir.

Sonuç olarak, pozitif mali demokrasi indeksi, kamu kesimine mali manevra kabiliyeti sağlarken, konjonktüre göre hızlı ayarlama yapılabileceğini de göstermektedir. Yine, mali demokrasi indeksindeki pozitif değerler, vatandaşların (vekiller vasıtasıyla) kamu harcamaları konusunda söz sahibi olduğunu ve bütçe katılığının sınırlılığını göstermektedir. 


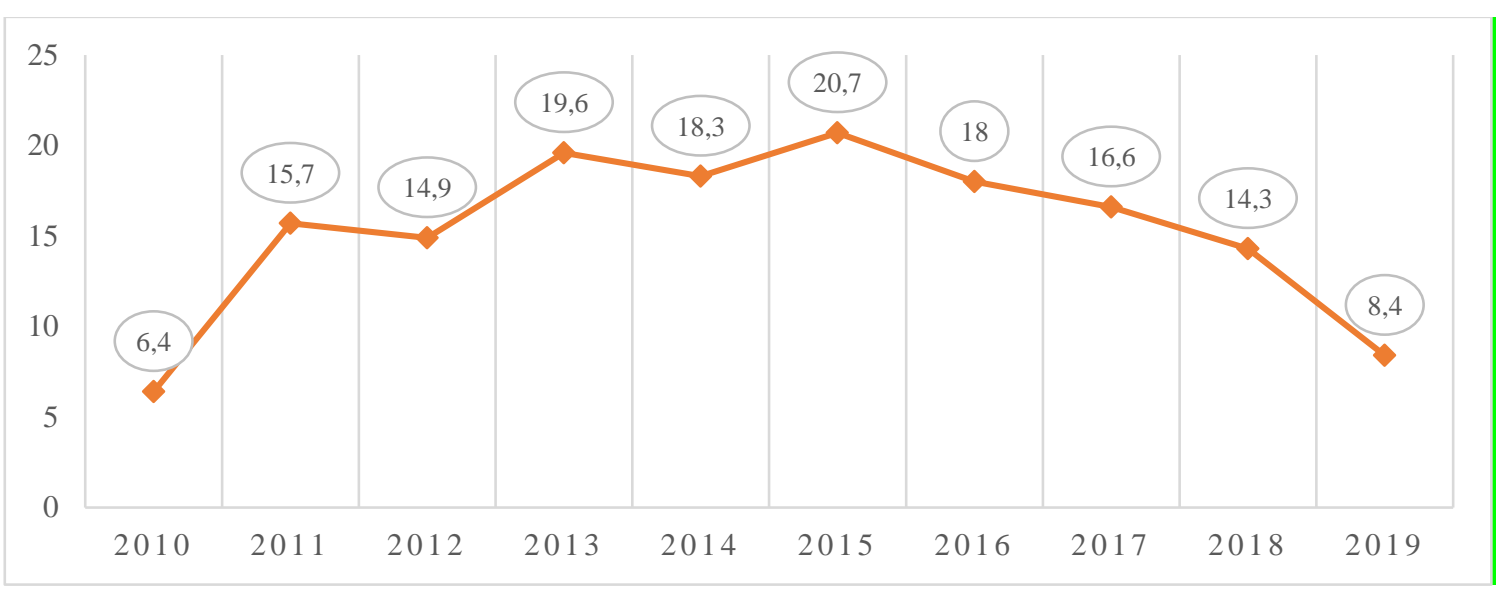

Grafik 2: Türkiye İçin Mali Demokrasi İndeksi (Savunma Harcamaları Dahil) (\%)

Kaynak: Yazarlar tarafindan oluşturulmuştur.

Not: Savunma harcamalart için TL cinsinden veriler SIPRI (2020)'den elde edilmiştir. Reel değer, ilgili nominal değerlerin Dünya Bankası (2020)'ndan alınan Türkiye GSYH Deflatörüne bölünmesi sonucu elde edilmistir. Elde edilen savunma harcamalart değerleri zorunlu harcamalara eklenmiş ve mali demokrasi endeksi tekrar hesaplanmıştır.

Grafik 2'de Türkiye için savunma harcamaları dahil edilmiş mali demokrasi endeksi görülmektedir. Her ne kadar bazı kaynaklarda (Bowen vd., 2014) savunma harcamaları isteğe bağlı harcamalar olarak addedilse de bazı kaynaklarda (Steuerle, 2014; Streeck ve Mertens, 2010; Roženský, 2011) mali demokrasi indeksi opsiyonel olarak savunma harcamaları eklenmiş biçimde sunulmuştur. Bu çalışmaları takiben savunma harcamaları eklenmiş şekilde oluşturulan mali demokrasi indeksinin savunma harcamaları eklenmemiş olan indeksten daha düşük değerler aldığı görülmektedir. Buna göre dünyada savunma harcamasının büyüklüğü konusunda ilk 15'te olan Türkiye'de savunma harcamalarının ülkenin harcama katılığını üzerindeki net etkisi Şekil 2 'de ortaya çıkmıştır. Öyle ki indeks genel olarak üçte bir oranında azalmıştır. Bu durumda Türkiye'de savunma harcamalarının mali demokrasiyi engellediği söylenebilmektedir.

\section{TÜRKIYYE VE BAZI ÜLKELERINN MALİ DEMOKRASI İNDEKSLERINIIN KARŞILAŞTIRILMASI}

Kurumsal düzenlemelerdeki farklılıklar, çok sayıda ülkede karşılaştırılabilecek uluslararası verileri sistematik olarak toplamanın önünde büyük bir engel oluşturduğundan, ülkeler arasında karşılaştırma yapmaya imkân verecek harcama katılıklarını ölçmek oldukça zordur (Muñoz ve Olaberria, 2019: 14). Daha önce değinildiği gibi öncelikle ülkeler için genel geçer bir katı harcama şablonu çizmek gerekmektedir. Öyle ki, örneğin bazı ülkelerde zorunlu olarak ele alınan sağlık harcamaları bazı ülkelerde sigorta yaptıran kişi tarafından karşılanmaktadır.

Ülkeler arası karşılaştırmayı zorlaştıran ve mali demokrasi indeksinin değerini etkileyen etkenlere örnek olarak şunlar verilebilir (Roženský, 2011: 136):

(i) Ülkeler arasında sosyal harcamaları karşılamanın farklı kaynakları vardır. Bu açıdan merkezi yönetim bütçesi yerine parafiskal fonların kullanılması,

(ii) Sağlı harcamalarının sigorta bütçesinden ya da alternatif olarak kamu bütçesinden karşılanması,

(iii) Sosyal yardımların vergilendirilmesi,

(iv) Vergi sisteminin kaynakları yeniden dağıtmaya yönelik bileşenleri,

(v) Özel zorunlu harcama programları, 
(vi) Ülkenin tarihsel gelişiminden veya diğer özel koşullardan kaynaklanan harcamaları,

(vii) Sosyal programların belediyelerin bütçesine aktarılması,

(viii) Toplam zorunlu harcamalara savunma harcamalarının dahil edilmesi, indeks değerini etkilemektedir.

Mali demokrasi indeksinin ülkeler arası karşılaştırmasında karşılaşılan en önemli zorluklardan bir diğeri zorunlu harcamaların ülkeler arasında farklılaşmasıdır. Bazı kaynaklarda (Herrera ve Olaberria, 2020) yapıldığı gibi zorunlu harcamaları genelleştirmek ise ülkeler arasında doğru sonuçlar vermeyen karşılaştırmaların yapılmasına neden olabilmektedir. $\mathrm{Bu}$ açıdan çalışmada çeşitli kaynaklarda farklı ülkeler için yer verilen zorunlu harcama içerikleri kullanılarak ABD, Almanya ve Bulgaristan ülkeleri için mali demokrasi indeksi hesaplanmıştır. Hesaplanan söz konusu değerler ile Türkiye'nin mali demokrasi indeksi değerlerine ilişkin karşılaştırma ise Grafik 3’ten görülebilir.

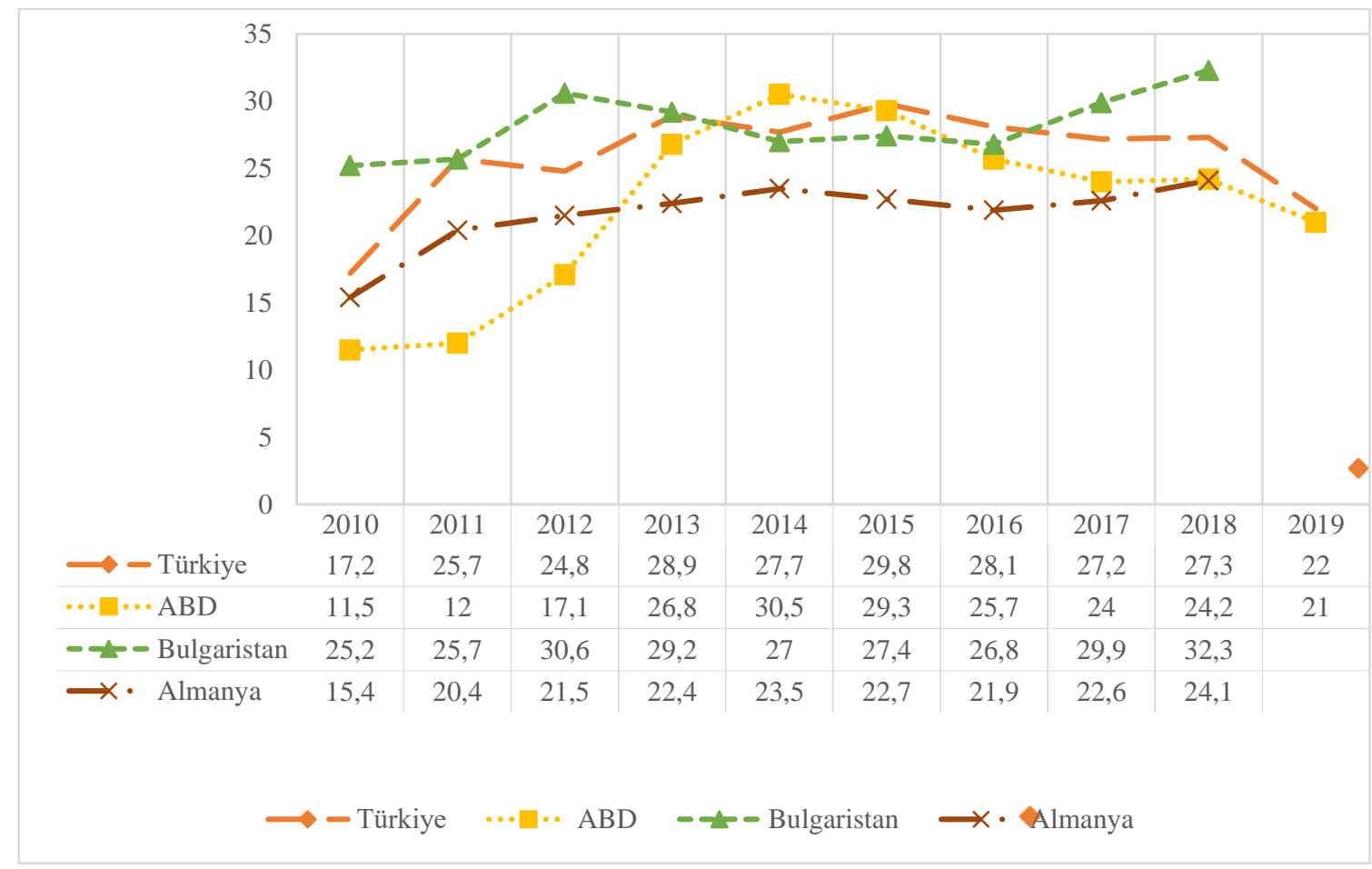

Grafik3:Türkiye ve Muhtelif Ülkelerde Mali Demokrasi İndeksi (\%)

Kaynak: Yazarlar tarafından oluşturulmuştur.

Not: ABD için zorunlu harcama içeriği ve verileri Congressional Budget Office (2020)'den kamu gelirleri Dünya Bankası (2020)'ndan elde edilmiştir. Almanya için zorunlu harcama içeriği Streeck ve Mertens (2010)'u takiben oluşturulmuş ve veriler Federal Maliye Bakanlı̆̆ı'nda bulunan Finanzbericht raporlarından ve veriler IMF (2020)'den elde edilmiştir. Bulgaristan için zorunlu harcama içeriği Rignold ve Lasagabster (2002)'i takiben oluşturulmuş ve IMF (2020)'den elde edilmiştir.

Grafik 3'te Türkiye ve çeşitli ülkelerin (ABD, Almanya ve Bulgaristan) mali demokrasi indekslerine yer verilmiştir. Buna göre ülkelerin indeks değerleri birbirine yakın ve bazı yıllarda eşit seyretmektedir. Türkiye 2010 yılından itibaren indeks değerinde artış görmesine rağmen 2019 'da söz konusu değer \%22'ye gerilemiştir. ABD'de 2010 yılından itibaren artan indeks değeri 2014 ve 2015 yıllarında zirve yapmış ancak daha sonra düşüş eğilimine girerek 2019'da \%21 olarak görülmüştür. Bulgaristan'ın indeks değeri görece yüksek ve dalgalı bir seyir izlemiştir. 2018 y1lı için Bulgaristan'ın mali demokrasi indeks değeri \%32,3'tür. Almanya'da ise indeks değeri 1lımlı bir artış trendindedir ve 2018'de \%24,1 olarak gerçekleşmiştir. 
Grafik 3'te de görüleceği üzere ülkelerin indeks değerleri negatif olmamakla birlikte yüksek değildir. Bu durum, açıkçası yüksek düzeyde olan ve son dönemde artış trendini sürdüren zorunlu (katı) harcamalardaki değişimi yansıtmaktadır (Herrera ve Olaberria, 2020: 17).

\section{SONUC}

Geçmiş yıllarda yasama ve diğer icra organlarınca alınan kararlar günümüzde karar verme iradesini de etkilemektedir. Kamu maliyesi alanında da benzer şekilde, geçmişte alınan kararların bugünün kararlarını etkilediği görülmektedir.

Geçmiş politikaların bir uzantısı olarak günümüzde birçok kamu harcaması kalemi zorunlu harcamalar sınıfına girmekte ve vergi gelirleri de doğası gereği geçmiş kararlardan etkilenmektedir. Mali demokrasi kavramı ile daha çok dikkate alınan bu gelişmeler ilgiyi zorunlu harcamalardan arta kalan kamu gelirlerine ve mali alan konusuna çekmiştir. Bu anlamda ülkedeki gelirlerden ne oranda ihtiyari harcamalar için pay kaldığı (artık gelir) önemli bir konu haline gelmiştir. Artık gelirin olmaması ya da mali demokrasi indeksinin negatif olması, yasama organının, o yıl için herhangi bir harcama programını oylamadan önce, mevcut gelirlerden daha fazlasının zorunlu harcama programlarına tahsis edilmesi anlamına gelmektedir. Buna karşıllk indeksin pozitif olması ise zorunlu kamu harcamaları yapıldıktan sonra ihtiyari harcamalara ayrılabilecek kamu gelirlerinin olduğunu göstermektedir.

Türkiye için yapılan hesaplamada mali demokrasi indeksi pozitif bulunmuştur. Ayrıca söz konusu indeks, diğer ülkeler ile paralellik arz etmektedir. Mali demokrasi indeksinin Türkiye için pozitif görünümde olması kamu gelirlerinden ihtiyari harcamalar için pay kaldığını, kamu gelirlerinin zorunlu harcamalardan daha fazla olduğunu göstermektedir. Ayrıca bu durum hükümetin ve dolayısıyla halkın (temsili demokrasi kanalıyla) vergi gelirleri ve kamu harcamaları üzerinde kısmen de olsa söz sahibi olduğunu göstermektedir. Şöyle ki, halkın temsilcilerinden oluşan meclis (TBMM) bütçeyi görüşmekte ve onaylamaktadır. Bütçede katı harcamaların az olması (mali demokrasi endeksinin yüksekliği) meclisin harcamalar üzerindeki yetkisini arttırmakta ve demokrasi daha etkin biçimde uygulanmış olmaktadır.

Mali demokrasi indeksindeki pozitif ve nispeten yüksek değerler, vergi gelirlerinden ihtiyari harcamalar için pay ayırabildiği ve anti konjonktürel maliye politikalarının etkinliğini artıracak mali alanın söz konusu olduğu anlamına gelmektedir. Bu durum aynı zamanda halkın bütçe üzerinde söz sahibi olduğuna işaret etmektedir. Buradan çıkartılabilecek bir başka önemli sonuç ise ekonomik istikrarsızlık (resesyon, depresyon vs.) dönemlerinde mali demokrasi endeksinin yüksek olmasının harcama disiplini sağlandığı anlamına gelmesidir.

Türkiye için hesaplanan mali demokrasi indeksi verilerinden birtakım politika önerileri çıkartılabilir. Çalışma bulguları ülkemizde mali demokrasinin pozitif olduğunu göstermekle birlikte; Belediyelere, SGK ve KİT gibi kuruluşlara aktarılan payların zorunlu harcamalar içinde önemli bir yer tuttuğunu ve son yıllarda artış eğiliminde olduğunu ortaya koymaktadır. $\mathrm{Bu}$ bağlamda mali demokrasideki stabil ve nispeten yüksek değerlerin zorunlu harcamaların azalması sonucu değil, artan vergi gelirlerinden kaynaklandığ 1 söylenebilir. Dolayısıyla başta Sosyal Güvenlik Kurumu (SGK) ve Kamu İktisadi Teşebbüsleri (KİT) reformu olmak üzere kamu harcamalarında etkinlik ve yerindelik disipliniyle tasarrufa gidilmesi gerekmektedir. Mahalli idarelerin yerel vergilerini artırma gayreti Merkezi yönetime bağımlılığını, transferleri azaltacak, böylece hem özerk bir yapıya hem de merkezi yönetim bütçesinde kullanılabilir fon artışına neden olunabilecektir. Diğer yandan gelir politikalarında sistemi iyileştirici, vergiyi tabana yayan, kayıt dışını azaltan, vergiye gönüllü uyumu sağlayan ve vergi yükünü adaletli dağıtacak düzenlemelerle de vergi performansı geliştirilebilir. 


\section{Araştırma ve Yayın Etiği Beyanı}

Bu çalışma bilimsel araştırma ve yayın etiği kurallarına uygun olarak hazırlanmıştır.

\section{Yazarların Makaleye Katkı Oranları}

Birinci yazarın makaleye katkıs1 \%50, İkinci yazarın makaleye katkısı \%50’dir.

\section{Çıkar Beyanı}

Yazarlar açısından ya da üçüncü taraflar açısından çalışmadan kaynaklı çıkar çatışması bulunmamaktadır.

\section{KAYNAKÇA}

Abdellatif, L. M., Zaky, M., Ramadan, M., Mazahreh, J. \&Elghandour, I. (2019). Transparency of law making and fiscal democracy in the Middle East. Public Sector Economics, 43(1), 49-77.

Allen, R., \&Tommasi, D. (2001). Managing public expenditure: A reference book for transition countries. Paris: OECD Publishing.

Austin, D. A. \&Levit, M. R. (2012). Mandatory spending since 1962. Crs report for congress. [Çevrimiçi: https://fas.org/sgp/crs/misc/RL33074.pdf], Erişimtarihi: 10.04.2020.

Ayyıldız Sayın, E.(2005a). Konsolide bütçeden kamu iktisadi teşebbüslerine yapılan transferler (1995-2004). Sayıştay Dergisi, 59, 89-118.

Ayyıldız Sayın, E. (2005b). Konsolide bütçe transferleri içinde kit transferlerinin yeri (1995-2004). [Çevrimiçi: http://www.acarindex.com/dosyalar/makale/acarindex-1423911647.pdf], Erişim tarihi: 02.03.2020.

Bowen, T. R., Chen, Y. \&Eraslan, H. (2014). Mandatory versus discretionary spending: The status quo effect. American Economic Review, 104(10), 2941-2974.

BÜMKO (2020). Bütçe büyüklükleri ve bütçe gerçekleşmeleri.[Çevrimiçi: http://www.bumko.gov.tr/TR,157/butcebuyuklukleri-ve-butce-gerceklesmeleri.html], Erişim tarihi: 14.07.2020.

Canbay, T. ve Demir, M. (2013). Türkiye'de sosyal güvenlik açıkları ve sosyal güvenlik ahlakı. Yönetim ve Ekonomi, 20(2), 303-315.

Çebi, C. (2015). Bütçe harcama katılığı. Türkiye Cumhuriyet Merkez Bankası Ekonomi Notları, Sayı: 2015-23.

Dünya Bankası (2020). Publicsector data. [Çevrimiçi: https://data.worldbank.org/topic/13 ], Erişim tarihi: 16.09.2020.

Fay, W. C. \& Rodgers, M. D. (2008). Appropriations for mandatory expenditures. Harvard Law School Federal Budget Seminar, Briefing Paper, No. 17.

Genschel, P. \& Schwarz, P. (2012). Tax competition and fiscal democracy, TranState Working Papers, No. 161.

Gelir İdaresi Başkanlığı (2020). Bütçe gelirleri (1923 - 2019).[Çevrimiçi: http://www.gib.gov.tr/sites/default/files/fileadmin/user_upload/VI/GBG1.htm], Erişim tarihi: 14.07.2020.

Gelir Politikaları Genel Müdürlüğü (2017). Gelir politikaları ve vergi düzenlemelerimiz. [Çevrimiçi: http: //www.gep.gov.tr/Pro/Dyn.aspx?prmts=31], Erişimtarihi: 20.09.2018.

Gümüş, E. (2010). Türkiye'de sosyal güvenlik sistemi: Mevcut durum, sorunlar ve öneriler. Seta AnalizAraştırmaNotu.

Hazine ve Maliye Bakanlığı (2017). Kamu işletmeleri raporu 2016.[Çevrimiçi https://www.hmb.gov.tr/kamusermayeli-kurulus-ve-isletmeler-raporlari], Erişim tarihi: 16.08.2019.

Hazine ve Maliye Bakanlığı (2020a). Merkezi Yönetim bütçe istatistikleri- sosyal güvenlik kurumlarl. [Çevrimiçi:https://ms.hmb.gov.tr/uploads/2019/04/Sosyal-G\%C3\%BCvenlik-Kurumlar\%C4\%B1.xls], Erişim tarihi: 14.07.2020.

Hazine ve Maliye Bakanlığı (2020b). Kamu sermayeli kuruluş ve işletmeler istatistikleri.[Çevrimiçi: https://www.hmb.gov.tr/kamu-sermayeli-kurulus-ve-isletmeler-istatistikleri], Erişim tarihi: 14.07.2020.

Hazine ve Maliye Bakanlığ1 (2020c). Bütçe gider-gelir gerçekleşmeleri (1924-2019). [Çevrimiçi: https://www.hmb.gov.tr/bumko-butce-buyuklukleri-ve-butce-gerceklesmeleri], Erişim tarihi: 14.07.2020. 
Herrera A.S.\&Olaberria, E. (2020). Budget rigidity in Latin America and the Caribbean: Causes, consequences, and policy implications. Washington: The World BankPublshing.

IFS (2017). Fiscal rigidities and their effects in Ghana. [Çevrimiçi: http://ifsghana.org/wpcontent/uploads/2017/02/Policy-Brief-3-Fiscal-Rigidities-and-their-Effects-in-Ghana.pdf],Erişim tarihi: 16.09.2020.

Ippolito, D. S. (2003). Why budgets matter: Budget policy and American politics. USA: The Pennsylvania State University Press.

(2013).

Turkeyselectedissuespaper

countryreportno.

13/364.[Çevrimiçi:https://www.imf.org/external/pubs/ft/scr/2013/cr13364.pdf], Erişim tarihi: 18.09.2018.

IMF (2020). Government finance statistics (GSF).[Çevrimiçi:https://data.imf.org/?sk=a0867067-d23c-4ebc-ad23d3b015045405 ], Erişim tarihi: 19.09.2020.

Itaborai, G. S. (2015). Proper management of the public good: Promoting efficiency and effectiveness of public spending. [Çevrimiçi:http://www.fazenda.rj.gov.br. ], Erişim tarihi: 20.09.2020.

Kraan, D. J. (1984). Towards more flexibility of government expenditure: Some recent developments in The Netherlands. Policy Sciences, 16(4), 413-427.

Levit, M. R., Austin, D. A., \& Stupak, J. M. (2015). Mandatory spending since 1962.[Çevrimiçi:https://fas.org/sgp/crs/misc/RL33074.pdf], Erişim tarihi: 25.09.2020.

Meklin, P., Liinavuori, J., \&Nummikoski, J. (2000). Expenditure inflexibility in the state budget: the fiscal policy latitude of the Council of State in Finland. Public Administration, 78(1), 193-207.

Muñoz, E., \&Olaberria, E. (2019). Are budget rigidities a source of fiscal distress and a constraint for fiscal consolidation?. World Bank Policy Research Working Paper, No. 8957

Mutluer, M. K. ve Öner, E. (2009). Teoride ve uygulamada mahalli idareler maliyesi. İstanbul: İstanbul Bilgi Üniversitesi Yayınları.

OECD (2013). Fiscal policy for development in the Dominican Republic. [Çevrimiçi:https://www.oecd.org/countries/dominicanrepublic/Fiscal\%20policy\%20for\%20development\%20in\%20th e\%20Dominican\%20Republic.E-Book.pdf], Erişimtarihi: 22.09.2018.

Öztürk, N.(2018). Kamu maliyesi. Bursa: Ekin Kitabevi.

Reuters (2019). Update 1-Brazil budget deficit widens more than forecast, pensions again the culprit.[Çevrimiçi:https://fr.reuters.com/article/brazil-economy-budget-idINL2N23X19V], Erişimtarihi: 19.09.2020.

Rignold, D. \&Lasagabster, E. (2002). Bulgaria: Public expenditure issues and directions for reform. World Bank Country Study, No. 26974.

Roženský, V. (2011). The effect of mandatory expenditure on fiscal flexibility. [Çevrimiçi:https://convention.vse.cz/media/Collection_2011_Volume_01.pdf], Erişimtarihi: 19.09.2020.

Roženský, V. (2012). Mandatornívýdaje a flexibilitafiskálnípolitiky v ČR. Politickáekonomie, 60(1) 40-57.

Sawhill, I. \&Anrig, G. (2010). Attention: deficit. Democracy A Journal of Ideas. [Çevrimiçi: https://democracyjournal.org/author/isawhillganrig/], Erişimtarihi: 01.09.2018.

Schiavo-Campo, S. (2017). Government budgeting and expenditure management: principles and international practice. New York: Taylor \& Francis.

Schmid, J. P., Waithe, K. \& Lorde, K. (2018). The hidden cost of weak budget projections-forecast deviation and debt buildup in Barbados. IDB Policy Brief, No. 304

Steuerle, C. E. (2012). Fiscal democracy or why sound fiscal policy, budget consolidation and inclusive growth require fewer, not more, attempts to control the future. In, L. Mello \& M. A. Dutz, (Eds), Promoting inclusive growth: challenges and policies.), (pp.147-177), Paris: OECD Publishing.

Steuerle, C. E.(2014). Dead men ruling how to restore fiscalfreedomandrescueourfuture. [Çevrimiçi:http://jay.law.ou.edu/faculty/jforman/ABA/ABAMay2015SteuerlePowerPoint.pdf], Erişim tarihi: 28.09.2018

Steuerle, E. (2016). Restoringfiscaldemocracy. $\quad$ The Milken InstituteReview, [Çevrimiçi:https://www.urban.org/sites/default/files/publication/80326/2000781-Restoring-FiscalDemocracy.pdf], Erişim tarihi: 27.09.2018.

Streeck, W. \&Mertens, D. (2010). An index of fiscaldemocracy. MPIfGWorkingPaper, No. 10/3. 
Streeck, W.\&Mertens, D. (2013). Publicfinanceandthedecline of statecapacity in democraticcapitalism. InA.Schäfer\& W.Streeck (Eds.), Politics in theage of austerity, (pp. 26-58), UK: PolityPress.

Şahin, H. (2016). Türkiye ekonomisi tarihsel gelişimi bugünkü durumu. Bursa: Ezgi Kitabevi.

TÜIKK (2020). Sağlık harcamaları istatistikleri.[Çevrimiçi: http://tuik.gov.tr/PreTablo.do?alt_id=1084], Erişim tarihi: 14.07.2020.

Ulusoy, A.ve Akdemir, T. (2017). Mahalli idareler teori uygulama maliye. Ankara: Seçkin Basım Yayın.

Ulusoy, A. ve Demir, M. A. (2018). İdarelerarası transferlerin rasyonel tasarımı. Gazi Üniversitesi Sosyal Bilimler Dergisi, 5(13), 263-277. 


\section{Extended Summary}

\section{Fiscal Democracy in Turkey: A Research for 2010-2019 Period}

The decisions of past policy makers have a significant impact on today's policies.In this regard, fiscal decisions made in the past have a significant impact on today's public spending and revenues.The fiscal policies implemented in the past affect today's policies as a policy legacy. Public expenditures are increasing as a result of various longstanding expenditures, such as public expenditures on social security programs and expenditures to close the budget deficits of state economic enterprises. The increase in these compulsory public expenditures reduces the decision-making power of current decision makers over the budget and undermines the democratic decision process. As a result, on the one hand the public's voice over the public budget decreases and on the other hand fiscal space gets lower and budget becomes inflexible.

The increase in compulsory public expenditures in recent years has caused these expenditures to cover the majority of tax revenues.As a result, the fiscal democracy index has been developed by Steuerle and Roeper.The Index measures the extent to which current tax revenues are spent by the legislature in compulsory public expenditure programs.The fiscal democracy index is calculated as follows: Compulsory public expenditures, which are the sum of compulsory public expenditures and debt interest service, are subtracted from the total public revenues. The obtained value indicates public revenues remaining in the budget for discretionary public expenditures. The ratio of this value to total public revenues constitutes the "fiscal democracy index". The negative financial democracy index shows that governments have no choice in tax revenues and expenditures. If the index is positive, it means that there is enough tax revenue left after compulsory public expenditures are made.

In order to calculate the fiscal democracy index, compulsory public expenditures must be determined. Accordingly, compulsory public expenditures vary from country to country. In this respect, in determining the compulsory public spending for Turkey, the IMF (2013) has been selected directory. Accordingly, compulsory public expenditures in Turkey arerevenues transferred from the central government budget to the Social Security Institution, revenues transferred to local administrations from the general budget, subsidies made to SEEs from the central government, current (goods and service expenditures) health expenditures and personnel expenses.

In this study, compulsory public expendituresconsisting of these expenditures were realized with the GDP Deflator obtained from the World Bank and presented in the study. Accordingly, compulsory public expenditures in Turkey are increasing in real terms.The said expenditures increased from 190.354 million Turkish Liras in 2010 to 273,035 million Turkish Liras in 2019.On the other hand, tax revenues also increased significantly during the period (2010-2019) under study.Tax revenues increased from 229,927 million Turkish Liras in 2010 to 350,259 million Turkish Liras in 2019. Tax revenues are in real terms greater than compulsory public expenditures.In addition, the rate of increase in tax revenues is relatively higher than the rate of increase in compulsory public expenditures.As a result, financial democracy index is positive in Turkey and has significantly higher values.Accordingly, the values of fiscal democracy index calculated for Turkey are 17.2 in 2010, 25.7 in 2011, 24.8 in 2012, 28.9 in 2013, 27.7 in 2014, 29 in 2015, 28.1 in 2016, 27.2 in 2017, 27.3 in 2018, and 22.0 in 2019.

According to the results obtained from study are, Turkey has a positive outlook for the fiscal democracy index. This shows that public revenues are greater than compulsory public expenditures and there is enough share of public revenue for discretionary spending. Moreover, this index values show that the government and therefore the people (through representative democracy) have some voice in tax revenues and public expenditures. Namely, the parliament 
(TBMM) consisting of the representatives of the people discusses and approves the public budget. The low level of compulsory expenditures in the budget (high financial democracy index) increases the authority of the parliament on expenditures and democracy is implemented more effectively. On the other hand, as a result of low public compulsory spending and high tax revenues, increasing fiscal democracy index values shows an increase in the public's fiscal maneuverability and fiscal space. It shows also faster fiscal adjustment according to conjuncture.

As a result of the fiscal democracy index values calculated for Turkey, it may be offered a number of policy proposals.Study findings indicate that positive financial democracy in Turkey. However, it reveals that the shares transferred to organizations such as Municipalities, Social Security Institution and State Economic Enterprises have an important place in compulsory expenditures and have an increasing trend in recent years. In this context, it can be said that stable and relatively high values in fiscal democracy are not due to the decrease in compulsory expenditures, but from increasing tax revenues. Therefore, it is necessary to make savings with the discipline of efficiency and appropriateness in public expenditures, especially with reform of the Social Security Institution (SGK) and State Economic Enterprises (SOE).The efforts of local administrations to increase their local taxes will reduce their dependence on the central government and transfers, thus leading to both an autonomous structure and an increase in available funds in the central government budget.On the other hand, tax performance can be improved by recovering the system in income policies, increasing tax base, reducing the informal economy, ensuring voluntary compliance with the tax and distributing the tax burden fairly. 